\title{
EFFECTS OF REVENUE DECENTRALIZATION ON ECONOMIC DEVELOPMENT: EMPIRICAL EVIDENCE FROM UKRAINE
}

\section{Kovalchuk A. V.}

\section{INTRODUCTION}

Though many studies have analyzed how FD (fiscal decentralization) contributes to economic growth, the determinants of FD have only recently begun to receive attention. In fact, little has been achieved in the theoretical research. ${ }^{1}$

${ }^{1}$ Martin, A. and Lewis, W. (1956) 'Patterns of Public Revenue and Expenditure', The Manchester School of Economics and Social Studies, 24(3), 203-244.

Litvack, J. and Oates, W. (1970) 'Group Size and the Output of Public Goods: Theory and Application to State-Local Finance in the United States', Public Finance, 25(1), 42-62.

Kee, W. (1977) 'Fiscal Decentralization and Economic Development', Public Finance Quarterly, 5(1), 79-97.

Bahl, R. and Nath, S. (1986) 'Public Expenditure Decentralization in Developing Economies', Environment and Planning C: Government and Policy, 4, 405-418.

Oates, W. and Schwab, R. (1988) 'Economic competition among jurisdictions: efficiency enhancing or distortion inducing?', Journal of Public Economics, 35(3), 333-354.

Panizza, U. (1999) 'On the Determinants of Fiscal Centralization: Theory and Evidence', Journal of Public Economics, 74(1), 97-139.

Arzaghi, M. and Henderson, J.V. (2005) 'Why countries are fiscally decentralizing', Journal of Public Economics, 89(7), 1157-1189.

Letelier, L. (2005) 'Explaining Fiscal Decentralization', Public Finance Review, 33(2), 155-183.

Freinkman, L. and Plekhanov, A. (2009) 'Fiscal decentralization in rentier regions: Evidence from Russia', World Development, 37 (2), 503-512.

Agénor, P.-R. and Yilmaz, D. (2012) 'Aid Allocation, Growth and Welfare with Productive Public Goods', International Journal of Finance \& Economics, 8(2). Available at: https://doi.org/10.1002/ijfe.465

Jílek, M. (2015) 'Factors of Tax Decentralization in OECD-Europe Countries', European Financial and Accounting Journal, 10(2), 33-49.

Canavire-Bacarreza, G., Martinez-Vazquez, J. \& Yedgenov, B. (2016) 'Reexamining the determinants of fiscal decentralization: what is the role of geography?' Journal of Economic Geography, 17(6), 1209-1249.

Jametti, M. and Joanis, M. (2016) 'Electoral competition as a determinant of fiscal decentralisation', Fiscal Studies, 37 (2), 285-300. 
Theoretically, since the nature and role of government changes during the economic growth of a country, then patterns of FD should differ for countries at different levels of growth. Regions in Ukraine are fairly similar in general conditions and level of development, possessing broadly the same culture, institutional structures, economic arrangement with related financial issues, and similar policies and approaches to solving these issues. However, there are also several dissimilarities between regions, mostly in historical aspects, geographical structures, and financial inflows.

This study considers the forces that play a role in FD, specifically a variety of social, political, geographic, and demographic variables, and evaluates the significance of the development of these forces. The research concentrates on the social spending and ability-to-pay approach, depending on the level of economic growth and average income in regions. It was the intent that this comparison provides a basis for discussing the patterns of FD from the perspective of a country's development.

It is important to remember that in any given country, FD has a unique history and prerequisites. It is reasonable, therefore, that crosscountry comparisons of this kind are subject to severe criticism. Obviously, there is no universally accepted criterion for measuring and judging economic performance, as each country sets different targets and faces various constraints, and different countries classify the same patterns of revenues differently.

Although there are certain disadvantages to looking at FD at the country level due to differences in measuring and the model specification needed to control for fixed effects specific to a country, it is also important to note that those differences and dynamic effects vary over time. For example, budgetary accounting systems and general government responsibilities and powers differ from one country to another in such a way that undermines the validity of measuring the associations between the decentralization coefficients across countries. Furthermore, reports on budgetary data given to international data sets (such as those of the World Bank and Organization for Economic Cooperation and Development (OECD) are sometimes inconsistent and show sizable fluctuation ${ }^{2}$. For example, there are non-trivial

Alexeev, M. and Mamedov, A. (2017) 'Factors determining intra-regional fiscal decentralization in Russia and the US', Russian Journal of Economics, 3(4), 425-444.

${ }^{2}$ Alexeev, M. and Mamedov, A. (2017) 'Factors determining intra-regional fiscal decentralization in Russia and the US', Russian Journal of Economics, 3(4), 425-444. 
discrepancies between the data gathered by the World Bank and OECD on the subnational government share of revenues in different countries. These discrepancies are the main reason the data for this study were collected from primary sources. Some fiscal and economic indicators and measures that appear in the budgets of countries are delegated to other agencies or left to institutions in other countries.

In fact, countries like Ukraine require gradual reorientation of authority. According to the Corruption Perceptions Index reported by Transparency International, Ukraine was the 126th least corrupt nation out of 180 countries in 2019, the 120th in 2018, and 130 or 131st over the 2017-2015 period $^{3}$, since 2014 (e.g., as mentioned earlier, the launching of administrative reforms and socio-economic crisis), making this conjecture more likely to be valid.

This study adds to the empirical research on the determinants of FD by exploring the decentralization policy of Ukraine. By considering data collected in the years following FD-2014 to 2017-Ukraine's situation offers an opportunity to analyze the forces that influence effective local fiscal policies and incentives in the early stages of FD in a developing country.

The following section describes the common approaches in the published empirical literature to the analysis of FD and the resulting revenue policies. Next, the theoretical forecasts and empirical predictions are discussed using relevant empirical evidence from recent literature, and the empirical methodology and techniques used in this study are introduced. The data is then discussed, the results are presented, and general conclusions are made. The basic statistics are laid out in three tables at the end of the study.

\section{Determinants of fiscal decentralization}

Naturally, the continuation of hostilities in the Donbas region in Ukraine led to the decentralization of the administrative and budget systems of the country, predetermining the time horizon and the crossregional specification of this investigation. Based upon the available research on the indirect effects of $\mathrm{FD}$, this research focuses on specific macroeconomic outcomes that may affect FD and which have been identified in the literature as potential determinants of poverty and income distribution, specifically regional economic growth,

\footnotetext{
${ }^{3}$ Trading Economics Data. Ukraine Corruption Rank1998-2019 Data. Available at: https://tradingeconomics.com/ukraine/corruption-rank, accessed July, 02, 2020.
} 
macroeconomic stability, regional convergence, the size of the public sector, and the degree of institutional development. To the extent that FD has a measurable impact on these outcomes, it is also indirectly expected to have a measurable effect on poverty and income distribution.

The following hypotheses were made:

Hypothesis $1(\mathrm{H} 1)$ : The more a population of a country is qualified and diverse, the more decentralized the country's regions will be. The diversification takes place upon efficient providing of public goods and services at a local level, and availability of local authority to access adequate sources to collect revenues. In particular, this kind of efficiency depends on the type of political system and the transparency - the degree to which the government is accountable to its citizens. This research considers the state government to be more efficient at expenditure allocation and the local government to be more efficient at revenue collection. Thus, the population as the measure of human capital quality increases FD, and population characteristics can be expected to positively influence FD.

Hypothesis 2 (H2): Regional size, both in land area and in population, is expected to affect FD. The assumption is that larger regions express more diversity in preferences among their population, and the more populous local entities possess an adequate area to produce local public goods more efficiently. Moreover, more extensive regions, with large land areas and high populations, are more difficult to administer from a single center - the country's capital. Thus, the population as a measure of regional size and area as a measure of regional size have an ambiguous effect on FD.

Hypothesis $3(\mathrm{H} 3)$ : An area with a higher share of rural population requires better and cheaper provision of public goods and a higher degree of development of transportation and communications networks. However, it is hard to forecast the relationship between urbanization and FD without controlling for the distribution of the rural population. There seems to be a positive correlation between FD and the proportion of the urban population on total population. In contrast, the rural population variable, coupled with low population density and increasing unemployment in remote areas, is expected to negatively correlate with FD in a developing country with a poor institutional environment.

Hypothesis 4 (H4): The ability-to-pay approach, which depends on the level of economic development in regions, diversifies income inequality, and has an ambiguous effect on FD. For instance, income inequality involves a diversity of tastes and thus fosters FD. It also 
requires expenditure redistribution, which is more efficient if it comes from the center, thus favoring centralization. Therefore, the relationship between personal income and FD is ambiguous.

Hypothesis 5 (H5): The level of economic development in terms of real Gross Regional Product (GRP) has an ambiguous effect on FD. Higher average incomes favor a diversity of preferences and foster FD, so GRP is a convenient indicator of economic growth. More prosperous regions are expected to be more fiscally decentralized. To observe description of the structural changes, institutional arrangements, and other reforms that are embodied in the development process, the following variables were considered: the INFL variable, which may have an ambiguous effect on GRP as FD affects economic growth differently in regions depending on the level of economic development, and the variables of openness, urbanization, and GRP, which may have a positive effect on FD as the business environment of an area shows its transparency, and a regional economy's openness, regional integration, and institutional factors contribute to regional economic growth. Further, INFL variable was dropped from regression equations as models appeared to be sensitive to adding insignificant variables).

Hypothesis $6(\mathrm{H} 6)$ : A region's dependence on transfers from a state government promotes economic growth in the early stages of decentralization. Here, transfers from the center flow directly to localities. In Ukraine, equalizing transfers requires smoothing out vertical and horizontal imbalances. Also, it is administratively more comfortable to make single-centered transfers; providing transfers of various sizes directly to the local government may create incentives for transfer recipients to relocate to localities with more generous provisions of equalization transfers.

\section{Data and technique}

This research employs control variables to determine the main factors that various authors have suggested as potential determinants for FD. These relate to the size of the region in land area, its demographic composition (geographical position, economic situation, and share of the rural population), and socio-economic measures (per-capita regional income variable and local budgets' dependence on intergovernmental transfers). These variables are similar to those used in earlier work on the determinants of FD. ${ }^{4}$ Other variables were considered, such as GRP

\footnotetext{
${ }^{4}$ Oates, W. (1972) Fiscal Federalism. New York: Harcourt Brace Jovanovich.
} 
dummy (subsets of regions categorized into two groups according to the GRP criteria), regional dummy (subsets of regions categorized into two groups upon belonging to the geographical east or west criteria), and inflation index, but they did not produce consistently significant estimates and did not qualitatively affect the findings, so they were dropped from the statistics layouts.

Some asides on log transforming the data, the study gives less priority to the normality of errors and indicates that for fundamental contrasts between conditions, additivity adheres regardless of logarithmic transformation. ${ }^{5}$ As it's typically more often the case, this research accounts for about validity, additivity, and linearity of the data giving priority to a short run.

The study focused on the degree of FD within regions, excluding Kyiv as a city with a special status, as it does not have conventional localities and is exempt from some of the rules governing fiscal relationships between regions and their constituent localities. We also excluded the Republic of Crimea and Sevastopol city (the second 'city of national significance' in Ukraine) because of the lack of data. To ensure clarity, the Donetsk and Luhansk regions were also excluded as political issues limited the available data. The final panel dataset contained information on 24 regions over four years, resulting in 96 observations.

Table 1 describes the variables and identifies their sources.

Panizza, U. (1999) 'On the Determinants of Fiscal Centralization: Theory and Evidence', Journal of Public Economics, 74(1), 97-139.

Arzaghi, M. and Henderson, J. (2005) 'Why countries are fiscally decentralizing', Journal of Public Economics, 89(7), 1157-1189.

Freinkman, L. and Plekhanov, A. (2009) 'Fiscal decentralization in rentier regions: Evidence from Russia', World Development, 37 (2), 503-512.

Canavire-Bacarreza, G., Martinez-Vazquez, J. \& Yedgenov, B. (2016) 'Reexamining the determinants of fiscal decentralization: what is the role of geography?' Journal of Economic Geography, 17(6), 1209-1249.

Jametti, M. and Joanis, M. (2016) 'Electoral competition as a determinant of fiscal decentralisation', Fiscal Studies, 37 (2), 285-300.

Alexeev, M. and Mamedov, A. (2017) 'Factors determining intra-regional fiscal decentralization in Russia and the US', Russian Journal of Economics, 3(4), 425-444.

Gelman, A. and Hill, J. (2007) Data Analysis Using Regression and Multilevel/Hierarchical Models. Cambridge University Press.

5 Gelman, A. and Hill, J. (2007) Data Analysis Using Regression and Multilevel/Hierarchical Models. Cambridge University Press. 
Description of variables and sources

\begin{tabular}{|c|c|}
\hline Variable & Description \\
\hline $\begin{array}{l}\text { Gross regional } \\
\text { product }(\mathrm{GRP})^{6}\end{array}$ & $\begin{array}{l}\text { Real GRP in millions of Ukrainian hryvnia (UAH). Source: } \\
\text { Regional Statistic, The State Statistics Service of Ukraine and } \\
\text { The Ministry of Finance Statistics for the years 2014-2017. } \\
\text { Source for the data: http://www.ukrstat.gov.ua/ and the author's } \\
\text { calculations. }\end{array}$ \\
\hline $\begin{array}{l}\text { Revenue } \\
\text { decentralization } \\
\text { (DEC_rev) }^{7}\end{array}$ & $\begin{array}{l}\text { Share of regional revenues in total consolidated revenues, } \% \text {. } \\
\text { The Ministry of Finance Statistics for the years 2014-2017. } \\
\text { Source for the data: https://mof.gov.ua/uk and the author's } \\
\text { calculations. }\end{array}$ \\
\hline $\begin{array}{l}\text { Transfer } \\
\text { dependence of } \\
\text { regional budget } \\
\text { (DEC_transf_re) }\end{array}$ & $\begin{array}{l}\text { Share of equalizing transfers (subventions) in total regional } \\
\text { revenues, \%. The Ministry of Finance Statistics for the years } \\
\text { 2014-2017. Source for the data: https://mof.gov.ua/uk and the } \\
\text { author's calculations. }\end{array}$ \\
\hline $\begin{array}{l}\text { Total Population } \\
\text { (Tot_pop) }\end{array}$ & $\begin{array}{l}\text { The annual population of the region in millions. Source: } \\
\text { Regional Statistics, The State Statistics Service of Ukraine for } \\
\text { the years 2014-2017. Source for the data: } \\
\text { http://www.ukrstat.gov.ua/ }\end{array}$ \\
\hline Area (AREA) & $\begin{array}{l}\text { Area of the region in thousand square kilometers. Source: } \\
\text { Regional Statistics for the years } 2014-2017 \text {. Source for the data: } \\
\text { http://www.ukrstat.gov.ua/druk/publicat/kat_u/2019/zb/12/zb_ru } \\
\text { 1ch2019.pdf }\end{array}$ \\
\hline $\begin{array}{l}\text { Share of the } \\
\text { rural population } \\
\text { (RURAL) }\end{array}$ & $\begin{array}{l}\text { Share of the rural population in the total regional population, \%. } \\
\text { Source: Regional Statistics for the years 2014-2017. Source for } \\
\text { the data: http://www.ukrstat.gov.ua/ and the author's } \\
\text { calculations. }\end{array}$ \\
\hline $\begin{array}{l}\text { Trade } \\
\text { of } \quad \text { regenness } \\
\text { economy, ratio } \\
\text { (OPENNESS) }\end{array}$ & $\begin{array}{l}\text { Openness index of the regional economy (enterprises that are } \\
\text { involved in import/ export as a share of real GRP in 2014-2017. } \\
\text { Source: Regional Statistics for the years 2014 } \\
\text { 2017.http://www.ukrstat.gov.ua/ and the author's calculations; }\end{array}$ \\
\hline
\end{tabular}

${ }^{6}$ The State Statistics Service of Ukraine; 2014-2017; Real GRP in millions of Ukrainian hryvnia (UAH); The annual population; Area of the regions; Enterprises that are involved in import/ export; Annual total personal income; Source for the data: http://www.ukrstat.gov.ua/

The Ministry of Finance; 2014 - 2017; Source for the data: https://index.minfin.com.ua/exchange/archive/nbu/curr/2017-12-

29/https://index.minfin.com.ua/exchange/archive/nbu/curr/2017-12-29/ 


\begin{tabular}{|c|c|}
\hline & $\begin{array}{l}\text { The data for currency rates were collected from the Ministry of } \\
\text { Finance of Ukraine official indexes of updates. Source for the } \\
\text { data: https://index.minfin.com.ua/exchange/archive/nbu/ } \\
\text { curr/2017-12-29/ }\end{array}$ \\
\hline $\begin{array}{l}\text { Personal income } \\
\text { (AverInc) }\end{array}$ & $\begin{array}{l}\text { Annual total personal income in millions UAH. Source: } \\
\text { Regional Statistics for the years } 2014-2017 \text {. Source for the data: } \\
\text { http://www.ukrstat.gov.ua/ }\end{array}$ \\
\hline $\begin{array}{l}\text { Hromadas } \\
\text { (HROMADAS) }\end{array}$ & $\begin{array}{l}\text { Annual quantity of united hromadas. }{ }^{8} \text { Source: Decentralization } \\
\text { Data. Source for } \quad \text { the } \\
\text { https://decentralization.gov.ua/gromada }\end{array}$ \\
\hline $\begin{array}{l}\text { Socio-economic } \\
\text { overall index } \\
(\text { INDEX) }\end{array}$ & $\begin{array}{l}\text { Composite democracy index data from the Ministry of Regional } \\
\text { Development, Construction and Housing and Communal } \\
\text { Services of Ukraine. The index represents a sum of ratings of } \\
\text { categories of economic, social, and institutional quality. Each } \\
\text { group is rated from } 1 \text { to } 25 \text {, with higher ratings representing } \\
\text { lower rank. Source: https://www.minregion.gov.ua/wp- } \\
\text { content/uploads/2016/05/Otsinka-sotsialno-ekonomichnogo- } \\
\text { rozvitku-regioniv-za-2015-r.-prezentatsiyni-materiali3.pdf }\end{array}$ \\
\hline GRPdummy & $\begin{array}{l}\text { Dummy variable to check for the sensitiveness of the regression } \\
\text { estimates between "wealthier" and "poor" regions, so-called } \\
\text { recipient and donor regions. The GRPdummy variable equals } \\
\text { one for "wealthier" regions and equals } 0 \text { for "poor" ones. } \\
\text { Source: Regional Statistics for the years } 2014-2017 \text { and the } \\
\text { author's calculations. Source for the data: } \\
\text { http://www.ukrstat.gov.ua/ }\end{array}$ \\
\hline
\end{tabular}

Source: own compilation

Table 2 presents the basic descriptive statistics for the variables. Note that both the range and the standard deviation of the dependent variables are reasonably significant.

${ }^{8}$ Decentralization Data; 2014-2017; Annual quantity of united hromadas ; Source for the data: https://decentralization.gov.ua/gromada

${ }^{9}$ The Ministry of Regional Development, Construction and Housing and Communal Services of Ukraine; 2014-2017; Composite democracy index data; Source: https://www.minregion.gov.ua/wp-content/uploads/2016/05/Otsinka-sotsialnoekonomichnogo-rozvitku-regioniv-za-2015-r.-prezentatsiyni-materiali3.pdf 
Descriptive statistics (2014-2017)

\begin{tabular}{|c|c|c|c|c|c|}
\hline Variable & Obs & Mean & Std. Dev. & Min & Max \\
\hline DEC_rev & 96 & .739 & .49 & .254 & 2.419 \\
\hline DEC_transf_rev & 96 & 61.329 & 8.519 & 38.297 & 76.307 \\
\hline OPENNESS & 96 & .754 & .505 & .219 & 3.07 \\
\hline RURAL & 96 & .581 & .14 & .37 & .908 \\
\hline GRP & 96 & 71638.604 & 53966.815 & 15049 & 313830 \\
\hline Tot_pop & 96 & 1654975 & 821871.04 & 905055 & 4297250 \\
\hline AverInc & 96 & 69557.302 & 41780.522 & 22941 & 245778 \\
\hline AREA & 96 & 2399.033 & 659.023 & 809.6 & 3331.4 \\
\hline HROMADAS & 96 & 8.406 & 6.705 & 1 & 28 \\
\hline INDEX & 96 & 13.5 & 6.959 & 2 & 25 \\
\hline GRPdummy & 96 & .344 & .477 & 0 & 1 \\
\hline \multicolumn{7}{|l|}{ Source: created by author using Shah (2018) } \\
\hline
\end{tabular}

In summary, some variables were taken directly from the data (GRP, average per capita income, etc.), while others were assembled by aggregating data from various sources.

\section{Model Estimation Strategy}

To estimate individual panel models, a particular weighting matrix in the form of contiguity weights was applied. A spatial autocorrelation was found, wherein spatial observations on neighboring regions are more similar than observations on regions that are far apart. This investigation uses dependent variable, that is: revenue decentralization. The systemGMM dynamic panel estimation was deemed as an appropriate approach, since the technique controls for potential endogeneities and serial correlation in terms of error and $\boldsymbol{\mu}$ (a vector of parameters representing the panel effects) is spatially correlated.

The time span chosen for our data was crucial for our research, as radical and rapid changes in inter-governmental budgetary, political, and social relations took place after 2014. Our data covers the period during which the administration reform was launched and Ukraine was dealing with a socio-economic and political crisis. After 2015, both revenues and expenditures were redistributed to the local levels, the taxation system was rearranged, and the system of intergovernmental budgetary transfers underwent improvement.

Model lestimated the regression of the revenue decentralization variable, as SDM is a generalization of the spatial autoregressive model 
(SAR) model and contains spatially weighted independent variables as explanatory variables ${ }^{10}$ :

FDit $=\rho W_{F D_{i t}}+\mathrm{Xit} \beta+\mathrm{W} Z_{i t} \theta+\mu+\epsilon_{i t}$,

SDM is generalized by applying spatial weights for the spatially lagged dependent variable (W FDit) and the spatially weighted regressors $\left(\mathrm{W} Z_{t}\right)$ to identify $Z_{t} \neq \mathrm{Xit}$. Table 3 shows the estimates of the revenue decentralization variable.

Table 3

Regression results for DEC_rev variable

\begin{tabular}{|c|c|c|c|c|c|c|c|}
\hline & (1) & (2) & (3) & (4) & (5) & (6) & (7) \\
\hline & OLS & $\underset{\mathrm{E}}{\mathrm{SDM}}$ & $\underset{E}{\text { SDM_F }}$ & $\begin{array}{l}\text { SDM } \\
\text { Lee Yu } \\
\text { spatial } \\
\text { effects }\end{array}$ & $\begin{array}{l}\text { SDM } \\
\text { (time- } \\
\text { fixed } \\
\text { effects) }\end{array}$ & $\begin{array}{l}\text { SDM } \\
\text { (spatial } \\
\text { time- } \\
\text { fixed } \\
\text { spatial } \\
\text { effects) }\end{array}$ & $\begin{array}{c}\text { SDM } \\
\text { (no } \\
\text { direct, } \\
\text { indirect, } \\
\text { and } \\
\text { total } \\
\text { effects) }\end{array}$ \\
\hline \multirow[t]{2}{*}{$\begin{array}{c}\text { DEC_transf_re } \\
\mathrm{v}\end{array}$} & $\overline{-}^{-} .5^{* * *}$ & $.025^{\text {**** }}$ & $.025^{* * *}$ & $.025^{* * * *}$ & $-.02 * * *$ & $.025 * * *$ & $.025^{-}$ \\
\hline & $(.003)$ & $(.007)$ & $(.003)$ & $(.003)$ & $(.004)$ & $(.004)$ & $(.003)$ \\
\hline \multirow[t]{2}{*}{ AREA } & 0 & 0 & 0 & 0 & 0 & 0 & 0 \\
\hline & (0) & (0) & (0) & (0) & (0) & (0) & (0) \\
\hline \multirow[t]{2}{*}{ AverInc } & $0 * * *$ & $0 * *$ & $0 * *$ & $0 * *$ & $0 * * *$ & $0 * *$ & $0 * * *$ \\
\hline & (0) & $(0)$ & $(0)$ & $(0)$ & (0) & $(0)$ & (0) \\
\hline \multirow[t]{2}{*}{ Tot_pop } & $0 * * *$ & 0 & $0 * * *$ & $0 * * *$ & 0 & $0 * *$ & $0 * *$ \\
\hline & (0) & (0) & (0) & (0) & (0) & (0) & (0) \\
\hline \multirow[t]{2}{*}{ GRP } & 0 & 0 & 0 & 0 & 0 & 0 & $0 * *$ \\
\hline & (0) & $(0)$ & $(0)$ & $(0)$ & (0) & (0) & (0) \\
\hline \multirow[t]{2}{*}{ RURAL } & .011 & $.153^{-} * * *$ & $.184^{-} * * *$ & $.184^{-} * * *$ & $258^{-} * * *$ & $-.145 * *$ & -.153 \\
\hline & $(.131)$ & $(.051)$ & $(.055)$ & $(.055)$ & $(.078)$ & $(.07)$ & $(.104)$ \\
\hline \multirow[t]{2}{*}{ OPENNESS } & $.143 * * *$ & $.114 * * *$ & $.075 * *$ & $.075^{* *}$ & $.032 * *$ & .027 & $.114 * * *$ \\
\hline & $(.029)$ & $(.033)$ & $(.035)$ & $(.035)$ & $(.016)$ & $(.031)$ & $(.03)$ \\
\hline \multirow[t]{2}{*}{ INDEX } & $-.01 * * *$ & -.001 & $.004 * * *$ & $.004 * * *$ & -.003 & $.004 * * *$ & -.001 \\
\hline & $(.002)$ & $(.005)$ & $(.001)$ & $(.001)$ & $(.002)$ & $(.001)$ & $(.003)$ \\
\hline \multirow[t]{2}{*}{ HROMADAS } & $.007 * * *$ & .002 & 0 & 0 & .003 & 0 & .002 \\
\hline & $(.002)$ & $(.002)$ & $(.001)$ & $(.001)$ & $(.002)$ & $(.001)$ & $(.002)$ \\
\hline \multirow[t]{2}{*}{ _cons } & $.992 * * *$ & 1.331 & & & & & $1.331 * *$ \\
\hline & $(.263)$ & $(1.076)$ & & & & & $(.622)$ \\
\hline
\end{tabular}

${ }^{10}$ Nickell, S. (1981) 'Biases in dynamic models with fixed effects', Econometrica, 49(6), 1417-1426. 


\begin{tabular}{|c|c|c|c|c|c|c|c|}
\hline $\begin{array}{c}\text { Wx:DEC_trans } \\
\text { f_rev }\end{array}$ & & .007 & $\overline{-}^{-} 017^{* * *}$ & $\overline{-}^{-} 017 * * *$ & -.006 & $-.021 * *$ & .007 \\
\hline & & $(.008)$ & $(.005)$ & $(.005)$ & $(.007)$ & $(.008)$ & $(.005)$ \\
\hline \multirow[t]{2}{*}{ Wx:AREA } & & 0 & 0 & 0 & $0 * *$ & 0 & $0 *$ \\
\hline & & (0) & (0) & (0) & (0) & (0) & (0) \\
\hline \multirow[t]{2}{*}{ Wx:AverInc } & & 0 & $0 * * *$ & $0 * * *$ & 0 & 0 & 0 \\
\hline & & (0) & (0) & $(0)$ & (0) & (0) & (0) \\
\hline \multirow[t]{2}{*}{ Wx:Tot_pop } & & 0 *** & $0 * *$ & $0 * *$ & 0 & 0 & $0 * * *$ \\
\hline & & (0) & (0) & (0) & (0) & (0) & $(0)$ \\
\hline \multirow[t]{2}{*}{ Wx:GRP } & & 0 & $0 * * *$ & $0 * * *$ & 0 & 0 & 0 \\
\hline & & (0) & (0) & $(0)$ & (0) & (0) & (0) \\
\hline \multirow[t]{2}{*}{ Wx:RURAL } & & .095 & .201 & .201 & -.274 & .171 & .095 \\
\hline & & $(.133)$ & $(.147)$ & $(.147)$ & $(.249)$ & $(.214)$ & $(.162)$ \\
\hline \multirow[t]{2}{*}{$\begin{array}{c}\text { Wx:OPENNES } \\
\mathrm{S} \\
\end{array}$} & & .065 & .05 & .05 & -.116 & -.111 & .065 \\
\hline & & $(.065)$ & $(.042)$ & $(.042)$ & $(.085)$ & $(.072)$ & $(.052)$ \\
\hline \multirow[t]{2}{*}{ Wx:INDEX } & & .004 & $.014 * * *$ & $.014 * * *$ & $.01 *$ & $.013 * * *$ & .004 \\
\hline & & $(.005)$ & $(.004)$ & $(.004)$ & $(.005)$ & $(.003)$ & $(.004)$ \\
\hline \multirow[t]{2}{*}{$\begin{array}{c}\text { Wx:HROMAD } \\
\text { AS } \\
\end{array}$} & & -.003 & -.004 & -.004 & $-.005^{* *}$ & -.003 & -.003 \\
\hline & & $(.003)$ & $(.003)$ & $(.003)$ & $(.002)$ & $(.003)$ & $(.003)$ \\
\hline \multirow[t]{2}{*}{ Spatial:rho } & & .072 & $.362^{-} * * *$ & $.362^{-} * * *$ & -.002 & $.422^{-} * * *$ & .072 \\
\hline & & $(.231)$ & $(.125)$ & $(.125)$ & $(.118)$ & $(.127)$ & $(.161)$ \\
\hline \multirow[t]{2}{*}{$\begin{array}{l}\text { Variance: } \\
\text { lgt_theta }\end{array}$} & & -.552 & & & & & -.552 \\
\hline & & (1.354) & & & & & $(.493)$ \\
\hline \multirow[t]{2}{*}{$\begin{array}{c}\text { Variance:sigma } \\
\text { 2_e } \\
\end{array}$} & & $.004 *$ & $.002 * * *$ & $.003 * * *$ & $.007 * * *$ & $.002 * * *$ & $.004 * * *$ \\
\hline & & $(.002)$ & $(.001)$ & $(.001)$ & $(.002)$ & $(.001)$ & $(.001)$ \\
\hline Observations & 96 & 96 & 96 & 72 & 96 & 96 & 96 \\
\hline R-squared & .941 & .951 & .714 & .714 & .861 & .674 & .951 \\
\hline Dummy & NO & NO & $\mathrm{NO}$ & $\mathrm{NO}$ & $\mathrm{NO}$ & NO & $\mathrm{NO}$ \\
\hline \multicolumn{8}{|c|}{$\begin{array}{l}\text { Robust standard errors clustered by region are in parentheses } \\
\text { Significance levels: } * * * \mathrm{p}<.01, * * \mathrm{p}<.05, * \mathrm{p}<.1 \\
\text { Source: created by author using } \operatorname{Shah}(2018)^{11}\end{array}$} \\
\hline
\end{tabular}

Likewise, Table 3 for revenue decentralization, the coefficients of labor force, income, socio-economic index, and the openness of the economy are significant in most of the specification models. The results

${ }^{11}$ Shah, A. (2018) ASDOC: Stata module to create high-quality tables in MS Word from Stata output. Statistical Software Components S458466, Boston College Department of Economics. 
of the variables on the area size (land area and population) are ambiguous. For instance, AREA regression is not meaningful at all specifications for revenue decentralization, with the population variable being statistically substantial in equations $1,3,4,6$ and 7 (Table 3). In contrast, equalization transfers are negative and significant in all revenue decentralization models (columns 1 through 7 of Table 3 ). The findings partially imply that subventions from upper governmental levels that are strictly prescribed to a particular use have a significant negative impact on FD. Thus far, further larger regions (in population size) tend to be more decentralized, which is consistent with conventional theory.

This article also exploits the evidence that for revenue decentralization in columns 3, 4 and 6 (Table 3) the rho coefficients show the spatial dependence in the data. Many expect the spatial dependence to enhance FD, but in Ukrainian regions, quite on the contrary, exists a significant negative influence of the neighboring oblasts on a given spatial unit.

The issue of government incentives is somewhat relevant for contemporary transition and developing countries. It was assumed that the area being measured may be small enough to produce significant impact on decentralization in most regions, specifically in terms of land area, lower cross-regional population density, and mobility. Here, we consider the rural population to represent the urbanization variable, as the impact might be similar. The study shows that in rural and sparsely populated areas, which are mainly bucolic areas in Ukraine, intraregional public institutions are weaker or are entirely missing so are not able to accommodate local desires adequately. Furthermore, centralization effects in the political and fiscal system in general were observed; the hromadas variable was significant in individual regressions in SDM regressions for revenue decentralization (column 1 of Table 3 ).

In particular, the share of transfers in total regional revenues reduced FD. This is a vital finding highlighting that strong fiscal incentive and a high degree of dependence on intergovernmental transfers leads to a poor horizontal distribution across regions over time. As for transfers' policy, Tables 3 shows the negative impact of transfers on fiscal policy, suggesting that horizontal distribution via transfers is more likely to inflow into subsequent equity issues, as revenues in wealthier regions tend to grow disproportionately faster relative to incomes in poorer regions.

Regression variables reflecting socio-economic and demographic setting contributed to the understanding of variation in dependent variables, while geographical structure proved to be insignificant. In 
parallel form, the effect of fiscal decentralization sensitivity may be due to the inputing of insignificant variables, such as GRP dummy variables, regional dummy variables, and the inflation index, which were all removed from the subsequent basic regression models.

In summary, the numerical effect of the variables is small, with a one standard deviation increase in each regression outcome with less than $1 \%$ change. GRP also has no statistically significant effect on decentralization. The situation is the same with the OLS results, wherein coefficients of the various factors in the OLS technique do not vary greatly from spatial effects specification, trials on GRP (laid out in table 4), or regional dummy variables.

Table 4

Regression results for DEC_rev variable with GRPdummy

\begin{tabular}{|c|c|c|c|c|c|c|c|}
\hline & (1) & (2) & (3) & (4) & (5) & (6) & (7) \\
\hline & OLS & $\underset{E}{\text { SDM_R }}$ & $\underset{E}{S D M \_F}$ & $\begin{array}{l}\text { SDM } \\
\text { Lee Yu } \\
\text { spatial } \\
\text { effects }\end{array}$ & $\begin{array}{l}\text { SDM } \\
\text { (time- } \\
\text { fixed } \\
\text { effects) }\end{array}$ & $\begin{array}{c}\text { SDM } \\
\text { (spatial } \\
\text { time- } \\
\text { fixed } \\
\text { spatial } \\
\text { effects) }\end{array}$ & $\begin{array}{l}\text { SDM } \\
\text { (no } \\
\text { direct, } \\
\text { indirect, } \\
\text { and } \\
\text { total } \\
\text { effects) }\end{array}$ \\
\hline \multirow[t]{2}{*}{$\begin{array}{c}\text { DEC_transf_re }_{\mathrm{v}} \\
\end{array}$} & $.014 * * *$ & $.027 * * *$ & $.027^{* * *}$ & $.027 * * *$ & $-.02 * * *$ & $.026 * * *$ & $.027 * * *$ \\
\hline & $(.003)$ & $(.005)$ & $(.004)$ & $(.004)$ & $(.005)$ & $(.004)$ & $(.003)$ \\
\hline \multirow[t]{2}{*}{ AREA } & 0 & $0 * *$ & 0 & 0 & 0 & 0 & $0^{*}$ \\
\hline & (0) & $(0)$ & (0) & $(0)$ & (0) & $(0)$ & $(0)$ \\
\hline \multirow[t]{2}{*}{ AverInc } & $0 * * *$ & $0 * * *$ & $0 * *$ & $0 * *$ & $0^{* * *}$ & 0 *** & $0 * * *$ \\
\hline & $(0)$ & $(0)$ & (0) & $(0)$ & (0) & (0) & $(0)$ \\
\hline \multirow[t]{2}{*}{ Tot_pop } & $0 * *$ & 0 & 0 *** & 0 *** & 0 & 0* & $0 * *$ \\
\hline & (0) & (0) & (0) & $(0)$ & (0) & (0) & $(0)$ \\
\hline \multirow[t]{2}{*}{ GRP } & $0^{*}$ & 0 & 0 & 0 & 0 & 0 & $0 * * *$ \\
\hline & $(0)$ & (0) & (0) & (0) & (0) & $(0)$ & $(0)$ \\
\hline \multirow[t]{2}{*}{ RURAL } & -.154 & ${ }^{-} 161^{* * *}$ & ${ }^{-} 171^{* * * *}$ & ${ }^{-} 171^{*} * * *$ & $\overline{2}^{-}$ & $-.155 * *$ & $-.161 *$ \\
\hline & $(.143)$ & $(.032)$ & $(.065)$ & $(.065)$ & $(.084)$ & $(.074)$ & $(.093)$ \\
\hline \multirow[t]{2}{*}{ OPENNESS } & $.142 * * *$ & $.11 * * *$ & $.082 * * *$ & $.082 * * *$ & .034 & .006 & $.11 * * *$ \\
\hline & $(.032)$ & $(.031)$ & $(.026)$ & $(.026)$ & $(.022)$ & $(.021)$ & $(.03)$ \\
\hline \multirow[t]{2}{*}{ GRPdummy } & .059 & $.082 * *$ & $.113 * * *$ & $.113 * * *$ & .001 & $.104 * * *$ & $.082 * *$ \\
\hline & $(.056)$ & $(.038)$ & $(.037)$ & $(.037)$ & $(.025)$ & $(.037)$ & $(.036)$ \\
\hline \multirow[t]{2}{*}{ _cons } & $.937 * * *$ & $1.396^{* *}$ & & & & & $1.396 * *$ \\
\hline & $(.298)$ & $(.707)$ & & & & & $(.635)$ \\
\hline
\end{tabular}




\begin{tabular}{|c|c|c|c|c|c|c|c|}
\hline $\begin{array}{c}\text { Wx:DEC_trans } \\
\text { f_rev }\end{array}$ & & .009 & -.002 & -.002 & -.006 & -.004 & $.009^{*}$ \\
\hline & & $(.006)$ & $(.005)$ & $(.005)$ & $(.007)$ & $(.007)$ & $(.005)$ \\
\hline \multirow[t]{2}{*}{ Wx:AREA } & & 0 & 0 & 0 & 0 & 0 & 0 \\
\hline & & (0) & (0) & (0) & (0) & (0) & (0) \\
\hline \multirow[t]{2}{*}{ Wx:AverInc } & & $0^{*}$ & $0 * * *$ & $0 * * *$ & 0 & 0 & 0 \\
\hline & & $(0)$ & (0) & (0) & (0) & $(0)$ & (0) \\
\hline \multirow[t]{2}{*}{ Wx:Tot_pop } & & $0 * * *$ & 0 & 0 & $0 * *$ & 0 & $0 * * *$ \\
\hline & & (0) & (0) & $(0)$ & (0) & (0) & (0) \\
\hline \multirow[t]{2}{*}{ Wx:GRP } & & 0 & $0 * *$ & $0 * *$ & 0 & 0 & 0 \\
\hline & & (0) & (0) & $(0)$ & (0) & (0) & (0) \\
\hline \multirow[t]{2}{*}{ Wx:RURAL } & & .128 & $.236 * *$ & $.236 * *$ & -.303 & .114 & .128 \\
\hline & & $(.119)$ & $(.097)$ & $(.097)$ & $(.236)$ & $(.131)$ & $(.137)$ \\
\hline \multirow[t]{2}{*}{$\begin{array}{c}\text { Wx:OPENNES } \\
\mathrm{S} \\
\end{array}$} & & .06 & .045 & .045 & -.099 & $-.177 * *$ & .06 \\
\hline & & $(.053)$ & $(.05)$ & $(.05)$ & $(.087)$ & $(.079)$ & $(.051)$ \\
\hline \multirow[t]{2}{*}{$\begin{array}{c}\text { Wx:GRPdumm } \\
\mathrm{y}\end{array}$} & & -.131 & -.071 & -.071 & -.033 & -.099 & -.131 \\
\hline & & $(.08)$ & $(.089)$ & $(.089)$ & (.134) & $(.084)$ & $(.08)$ \\
\hline \multirow[t]{2}{*}{ Spatial:rho } & & .019 & -.017 & -.017 & -.125 & -.119 & .019 \\
\hline & & $(.129)$ & (.09) & (.09) & $(.125)$ & $(.098)$ & $(.147)$ \\
\hline \multirow[t]{2}{*}{$\begin{array}{c}\text { Variance:lgt_th } \\
\text { eta }\end{array}$} & & $-.996 *$ & & & & &.$\overline{-}$ \\
\hline & & $(.512)$ & & & & & $(.274)$ \\
\hline \multirow[t]{2}{*}{$\begin{array}{c}\text { Variance:sigma } \\
\text { 2_e }\end{array}$} & & $.004 * * *$ & $.002 * * *$ & $.003 * * *$ & $.008 * * *$ & $.002 * * *$ & $.004 * * *$ \\
\hline & & $(.001)$ & $(.001)$ & $(.001)$ & $(.003)$ & $(.001)$ & $(.001)$ \\
\hline Observations & 96 & 96 & 96 & 72 & 96 & 96 & 96 \\
\hline R-squared & .923 & .936 & .736 & .736 & .885 & .675 & .936 \\
\hline Dummy & YES & YES & YES & YES & YES & YES & YES \\
\hline \multicolumn{6}{|c|}{ Robust standard errors clustered by region are in parentheses } & & \\
\hline
\end{tabular}

\section{CONCLUSIONS}

This section provides discussion and comments on how regional features influence decentralization in Ukraine. Taken together, the findings of the regressions tend to support the idea that FD is a function of control variables. One may doubt that there is enough significant difference between regions to observe the actual forces that affect FD. For this reason, researchers recognize the existence of spatial spillovers, which, in theory, decline as the distance between regions increases. Here, spatial panel data models were used to empirically measure such 
spillover. Such an approach is intended to provide a more complex image of the topic and open multiple avenues to consistent research and versatile analysis.

This investigation reveals a negative spatial dependence of neighboring oblasts in terms of revenue decentralization. This gives a winning strike, first, for the donors of subsidies to tend to launch business reform slower than subsidy-receiving oblasts in Ukraine; second, local government in "wealthier" oblasts had tend more to fiscal autonomy and have had more fiscal power than in "poor" oblasts (evidence from columns 2 through 4 and 6, 7 of Table 4). The OLS specifications concerning revenue decentralization, unexpectedly, are less appropriate than spatial regressions for regions within a single country, by so spatial specifications are more consistent.

It is obvious that regions of greater land area and population pay more in order to provide decentralized government representation. As is often the case, dissimilar estimation criteria led to conflicting conclusions. While some public functions remain in the capital, others are dispersed around the regions. Surprisingly, in all spatial models (Tables 3 and 4), the coefficients of the size of the region (land area and population) are ambiguous, with land area being statistically insignificant and total population being significant in all equations. It was expected by hypothesis $\mathrm{H}(2)$ that FD would be responsive to the size of regions but didn't find support in research outcomes. These findings also imply that the higher the population density, the more regions tend to decentralize, which is consistent with conventional theory, so the hypothesis $\mathrm{H}(1)$ is somehow confirmed with weak evidence.

Furthermore, the results of most of the SDM specifications continued to indicate that land area is not always a significant explanatory variable in the patterns of FD. Considered together with the negative statistically significant coefficients on rural population proportion in total population $(\mathrm{H}(3)$ is confirmed), equalizing transfers, and insignificant GRP variables (which likely reflect the potential ability of rural communities to organize and guarantee social services), one might assume that revenue decentralization in rural areas cannot be robust. Presumably, remoteness from the capital or other decision-making centers pushes distant areas to rely on equalizing transfers and to forcefully demand social services. As is more often the case, remote regions with large areas are, to some extent, still neglected in the provision of high-quality social services and public goods but are the main recipients of grants and public transfers. 
The hypothesis $\mathrm{H}(4)$ on average income was confirmed to have ambiguous effect on FD. Average income is the most significant variable affecting FD. The statistics identified wealthier regions as the welfare donors, and governments of a lower status are untenable to the encroachment of superior governments. Since local area governments have limited means with which to protect their fair share of the resource chain, the whole system depends on the fiscal self-discipline of the superior governments.

Several variables affect FD; while average income is slightly significant, it is not the only variable. Also, according to our investigation, since 2014, intergovernmental fiscal relationships and other institutional changes have significantly redistributed the factors influencing intraregional FD.

The hypothesis $\mathrm{H}(6)$ on transfer policy was rejected by this study. Equalizing transfer spending appears to be negatively related to revenue decentralization specifications. Socio-economy conditions are significant at all levels in some regressions, but slightly correlate to revenue decentralization (columns 1, 4, 6 of Table 3), and trade openness (hypothesis $\mathrm{H}(5)$ confirmed to produce positive and statistically significant correlation with revenue decentralization. The existence of hostile neighbors negatively affected the allocation of funds and, to some extent, reflects the transmuting environment and roles of public institutions in time of crisis and corruption in a developing country like Ukraine.

Countries in transition or developing require the gradual reorientation of the role of the country's authorities from one that centrally commands and controls fiscal relations to one that fosters decentralized markets. To adequately explain the process of FD as a complicated one and one subject to many internal and external influences, this study considered social, political, geographical, and economic patterns. Further findings indicated that the determinants of FD somehow depend on more than the level of development as measured by average income, but absolutely do not depend on the level of development as measured by GRP, by so hypothesis $\mathrm{H}(5)$ is rejected.

If the observed variables are able to capture several of the structural changes that accompany development, then the determinants of FD will change as a country develops. While this study did not consider all of the possible variables, it did identify some directions that should be considered by future research, including the extent to which advancement changes the social, economic, and political character of a country itself. 
It is hoped that the outcome of this study shows that while we were unable to grasp the specific variation of revenue decentralization and its determinants, FD can be explained considerably by the variables the study observed. The degree of FD changes with the level of development, and increases in average income, GRP, socio-economic index, trade openness, decreases in rural residence, and equalizing transfers received may indicate a higher level of development and result in the deliberate increasing of social expenditures.

SDM estimates are likely to be the aftereffects of various estimation techniques and variable preferences. It is possible that spatial panel analysis better captures all the characteristics that contribute to the differences between the factors affecting decentralization. We found neither regional components nor intraregional FD to consistently donate to the degree of economic development in regions in Ukraine.

While the findings here were limited, they point out that FD depends on geographic, financial (equalization transfers), demographic, and socio-economic measures. Most disappointing were the findings from the SDM regressions, which were slightly different from zero, and the lame dummy variable tests indicating the slope parameters of the geographical size, inflation index, and location of the regions.

Additional work is clearly needed. Revenues are centralized in Ukraine such that the central government mobilizes more revenue sources through the revenue collection system, having a negative impact on economic growth. This research suggests it is better to use taxes closer to their origins than to provide areas with additional support through equalization transfers; additional research on patterns of revenue sources will clarify this further.

\section{SUMMARY}

This investigation compares the patterns of FD ascribable to public revenues in 24 regions in Ukraine, emphasizing the geographic, economic, and human capital aspects. Regional differences may not affect the variation in the underlying economic, social, and demographic patterns, in which case the issue of the determinants of FD requires further analysis. Given the growing geopolitical tensions and slowing economic dynamics, the number of regions in which budgets are approved with a deficit continues to increase in Ukraine, as does the debt burden on local budgets, which compounds the current and future problems in socio-economic development. 


\section{REFERENCES}

1. Agénor, P.-R. and Yilmaz, D. (2012) 'Aid Allocation, Growth and Welfare with Productive Public Goods', International Journal of Finance \& Economics, 8(2). Available at: https://doi.org/10.1002/ijfe.465

2. Alexeev, M. and Mamedov, A. (2017) 'Factors determining intraregional fiscal decentralization in Russia and the US', Russian Journal of Economics, 3(4), 425-444.

3. Arzaghi, M. and Henderson, J.V. (2005) 'Why countries are fiscally decentralizing', Journal of Public Economics, 89(7), 1157-1189.

4. Bahl, R. and Nath, S. (1986) 'Public Expenditure Decentralization in Developing Economies', Environment and Planning C: Government and Policy, 4, 405-418.

5. Canavire-Bacarreza, G., Martinez-Vazquez, J. \& Yedgenov, B. (2016) 'Reexamining the determinants of fiscal decentralization: what is the role of geography?' Journal of Economic Geography, 17(6), 1209-1249.

6. Decentralization Data; 2014-2017; Annual quantity of united hromadas ; Source for the data: https://decentralization.gov.ua/gromada

7. Freinkman, L. and Plekhanov, A. (2009) 'Fiscal decentralization in rentier regions: Evidence from Russia', World Development, 37 (2), 503-512.

8. Gelman, A. and Hill, J. (2007) Data Analysis Using Regression and Multileve1/Hierarchical Models. Cambridge University Press.

9. Jametti, M. and Joanis, M. (2016) 'Electoral competition as a determinant of fiscal decentralisation', Fiscal Studies, 37 (2), 285-300.

10. Jílek, M. (2015) 'Factors of Tax Decentralization in OECD-Europe Countries', European Financial and Accounting Journal, 10(2), 33-49.

11. Kee, W. (1977) 'Fiscal Decentralization and Economic Development', Public Finance Quarterly, 5(1), 79-97.

12. Letelier, L. (2005) 'Explaining Fiscal Decentralization', Public Finance Review, 33(2), 155-183.

13. Litvack, J. and Oates, W. (1970) 'Group Size and the Output of Public Goods: Theory and Application to State-Local Finance in the United States', Public Finance, 25(1), 42-62.

14. Martin, A. and Lewis, W. (1956) 'Patterns of Public Revenue and Expenditure', The Manchester School of Economics and Social Studies, 24(3), 203-244.

15. Nickell, S. (1981) 'Biases in dynamic models with fixed effects', Econometrica, 49(6), 1417-1426. 
16. Oates, W. (1972) Fiscal Federalism. New York: Harcourt Brace Jovanovich.

17. Oates, W. and Schwab, R. (1988) 'Economic competition among jurisdictions: efficiency enhancing or distortion inducing?', Journal of Public Economics, 35(3), 333-354.

18. Panizza, U. (1999) 'On the Determinants of Fiscal Centralization: Theory and Evidence', Journal of Public Economics, 74(1), 97-139.

19. Shah, A. (2018) ASDOC: Stata module to create high-quality tables in MS Word from Stata output. Statistical Software Components S458466, Boston College Department of Economics.

20. The Ministry of Finance; 2014-2017; Budget of Ukraine; Source for the data: https://mof.gov.ua/uk

21. The Ministry of Regional Development, Construction and Housing and Communal Services of Ukraine; 2014-2017; Composite democracy index data; Source: https://www.minregion.gov.ua/wpcontent/uploads/2016/05/Otsinka-sotsialno-ekonomichnogo-rozvitkuregioniv-za-2015-r.-prezentatsiyni-materiali3.pdf

22. The State Statistics Service of Ukraine; 2014-2017; Real GRP in millions of Ukrainian hryvnia (UAH); The annual population; Area of the regions; Enterprises that are involved in import/ export; Annual total personal income; Source for the data: http://www.ukrstat.gov.ua/

23. Trading Economics Data. Ukraine Corruption Rank1998-2019 Data. Available at: https://tradingeconomics.com/ukraine/corruptionrank, accessed July, 02, 2020.

\section{Information about the author:} Kovalchuk A. V., Postgraduate Student Shandong University 27, Shanda Nanlu, Jinan, 250100, China, National Academy for Public Administration under the President of Ukraine 20, Antona Tsedika str., 03057, Kyiv, Ukraine 